\title{
TWO DECADES OF REALISTIC MATHEMATICS EDUCATION RESEARCH IN INDONESIA: A SURVEY
}

\author{
Rully Charitas Indra Prahmana*1, Laela Sagita ${ }^{2}$, Wahyu Hidayat ${ }^{3}$, Niken Wahyu Utami ${ }^{2}$ \\ ${ }^{1}$ Universitas Ahmad Dahlan, Yogyakarta, Indonesia \\ ${ }^{2}$ Universitas PGRI Yogyakarta, Yogyakarta, Indonesia \\ ${ }^{3}$ Institut Keguruan dan Ilmu Pendidikan Siliwangi, Cimahi, Indonesia
}

\begin{tabular}{l}
\hline \hline Article Info \\
\hline Article history: \\
Received May 26, 2020 \\
Revised Aug 30, 2020 \\
Accepted Sep 29, 2020
\end{tabular}

\section{Keywords:}

Freudenthal's idea, Indonesia,

Mathematics education approach,

Realistic mathematics

education,

Survey

\begin{abstract}
Freudenthal's ideas on mathematics that stated mathematics as a human activity and mathematics must be connected to reality have colored towards learning mathematics all over the world, including Indonesia. Existing research on this topic in Indonesia among two decades is categorized and compared. This paper presents a systematic literature review of empirical studies on this learning approach in Indonesian context. The implementation of this approach in Indonesia was analyzed comprehensively and divided into several major topics. Resources of this research come from 110 articles by ten highest rank accredited journals by the Ministry of Research, Technology, and Higher Education, the Republic of Indonesia as an achievement for the peerreviewed journal, which has excellent quality in management and publication. The results show that there are seven categories summarized in this research: the dominance of published RME articles, RME research subjects, mathematical topics, students' abilities, RME terms, and the research method used in RME articles. Lastly, the summarized 110 papers are displayed in the table to give essential information as a fundamental idea for further RME research.
\end{abstract}

Copyright () 2020 IKIP Siliwangi. All rights reserved.

\section{Corresponding Author:}

Rully Charitas Indra Prahmana,

Departement of Mathematics Education,

Universitas Ahmad Dahlan,

Jl. Pramuka No. 42, Pandeyan, Umbulharjo, Yogyakarta, Indonesia.

Email: rully.indra@mpmat.uad.ac.id

\section{How to Cite:}

Prahmana, R. C. I., Sagita, L., Hidayat, W., \& Utami, N. W. (2020). Two Decades of Realistic Mathematics Education Research in Indonesia: A Survey. Infinity, 9(2), 223-246.

\section{INTRODUCTION}

Realistic Mathematics Education (RME) is a specific mathematics instruction theory from the Netherlands (Van den Heuvel-Panhuizen \& Drijvers, 2020b). The basis of it is mathematics often out of the students' thoughts, so mathematics instruction must be connected to reality, or use context problems. Context problems in RME are used from the beginning until the end of a learning sequence to add on (Gravemeijer \& Doorman, 1999). Therefore, RME can be used to color the approach to learning mathematics.

$\mathrm{RME}$ is adopted in many countries, including Indonesia. Indonesian version of RME is known as Pendidikan Matematika Realistik Indonesia (PMRI) or Pendidikan Matematika 
Realistik (PMR). The history of the development of RME in Indonesia began since the publication of articles about RME in the JPM (one of the national journals in Indonesia) in 2007. RME continues to grow in Indonesia, as seen from the increasing number of RME articles published in various national journals in Indonesia. There are multiple variations of RME articles in Indonesia, such as literature studies, design research, case studies, classroom action research, and experiments.

These various articles are coloring the use of RME on mathematical education research in Indonesia since 2007. RME in Indonesia for two decades has been discussed by Zulkardi, Putri, and Wijaya (2020). Zulkardi, Putri, and Wijaya (2020) reported the process of adapting, implementing, and developing RME to the Indonesian context over the past two decades. Their explanation starts from the history of how RME came to Indonesia, how RME is learned from the Netherlands, how RME is implemented, disseminated, and developed in Indonesia. Furthermore, the history continues to discuss initiative several activities namely the International Master's Program on Mathematics education (IMPoME), the International Conference on Design Research (SEA-DR), the Mathematical Literacy Contest (KLM) and the Context-Based Mathematics Tasks Indonesia (CoMTI) project, the web portal on PMRI set up by the P4MRIs, the Course on Realistic Mathematics Education for Junior Secondary School Mathematics Teachers in Southeast Asia (SEA-RME course), and the Journal on Mathematics Education (JME). The journal, namely Journal on Mathematics Education as the last initiative activity, is one of this article's resources.

However, Zulkardi, Putri, and Wijaya (2020) do not explain the significant topics in the various articles on applying RME into categories to obtain the RME classification in Indonesia. This article would comprehensively analyze and divide them into groups to receive the RME classification major topics in Indonesia. We can use this classification to add theories related to the development of RME in Indonesia in the last two decades.

\section{METHOD}

This paper is a survey paper. We used the sample, which comes from ten highest rank accredited journals by the Ministry of Research, Technology, and Higher Education, the Republic of Indonesia, as an achievement for the peer-reviewed journal with excellent management and publication quality. Ten journals have been accredited in categories 1 and 2. In the first category, there is the Journal on Mathematics Education (JME). Next, there are nine journals in the second category, namely Jurnal Riset Pendidikan Matematika (JRPM), Infinity Journal (Infinity), Beta: Jurnal Tadris Matematika (Beta), International Journal on Emerging Mathematics Education (IJEME), Al-Jabar: Jurnal Pendidikan Matematika (AlJabar), Jurnal Pendidikan Matematika (JPM), Jurnal Elemen (Elemen), Journal of Research and Advances in Mathematics Education (JRAMathEdu), and AKSIOMA: Jurnal Program Studi Pendidikan Matematika (AKSIOMA). This paper analyzed 110 papers published over the last 14 years from January 2007 to March 2020 in these ten accredited journals. The keywords used by researchers in collecting these reviewed articles are Realistic Mathematics Education, Pendidikan Matematika Realistik Indonesia, Pendidikan Matematika Realistik, and Indonesian Realistic Mathematics Education.

The journal papers were analyzed according to the criterion of term realistic research on mathematics education. We started our research analysis by searching for the word "realistic" and "realistik" within each journal on ten highest rank accredited journals by the Ministry of Research, Technology, and Higher Education, the Republic of Indonesia. Furthermore, we classified all contributions from these papers, such as titles, years, journal names, topics of the studies, context, research subject, mathematics content, and mathematics ability of the courses. 
This paper aims to conduct a comprehensive study of the existing research on RME in Indonesia among two decades. We analyzed comprehensively, categorized, compared, and divided the implementation of this approach in Indonesia into several major topics. We present categories on RME articles based on the dominance of published RME articles, RME research subjects, mathematical topics, students' abilities, RME terms, and the research method used in the RME articles. The categories are obtained from various papers and articles that can be accessed and then affirmed by our interpretations as a team of researchers. The discussion begins with the number of RME articles published in each journal.

Further studies regarding some of the RME research subjects, mathematical topics, students' abilities, RME terms, and the research method is used in RME articles. In every section, we report the percentage of contributions assigned to each category. In the last section, we write separately on the table of RME Research Paper resumes in Indonesia.

\section{RESULTS AND DISCUSSION}

\subsection{Trends of RME Articles on Various Journals in Indonesia}

The trend of Realistic Mathematics Education publication from 10 journals from 2007 to 2013 has increased in the number of articles. Both articles published in the JPM became the starting point of the stretching of the publication of RME papers in Indonesia. JPM became the first journal to publish two RME articles in 2007. Soedjadi (2007), in his article, explained the philosophical basis, theoretical basis (RME principle), applicative basis, and the impact of realistic mathematics education. Furthermore, the second article published in JPM Journal in 2007 discusses the development of teacher manuals that are equipped with student books, student worksheets, play activities, enrichment activities, and remedial activities (Amin, 2007).

The number of publications decreased by $54 \%$ in 2014 . Furthermore, the number of articles published has fluctuated until 2017. On the other hand, the number of publications has increased again until 2018 and reached the highest number in 2019 of 15 articles scattered in AKSIOMA, Al-Jabar, JME, IJEME, Infinity, and JRAMathEdu. Based on the number of RME article releases each year, JME and JPM are journals that consistently produce papers with RME scope. It can be seen in most JME word count keywords, namely Research Design, RME, and PMRI.

The number of RME articles published by JME is 37 articles until 2020. This number is the highest number of articles from other journals in proportion to the age of JME. The first RME article published by JME in 2010 discussed the effectiveness of RME in improving problem-solving ability in Yogyakarta for Junior High School Students (Sugiman $\&$ Kusumah, 2010). JPM, as a pioneer journal of RME articles in Indonesia until 2020, has published 26 articles with even distribution each year. The number of RME articles that have been published by each journal is directly proportional to each journals' age.

Based on the analysis, the dominance of RME articles is in JME and JPM. RME articles in the JME are more than one-third of all RME articles, while RME articles in the JPM are almost a quarter of all RME articles. The number of RME articles in each journal shown in Figure 1. 


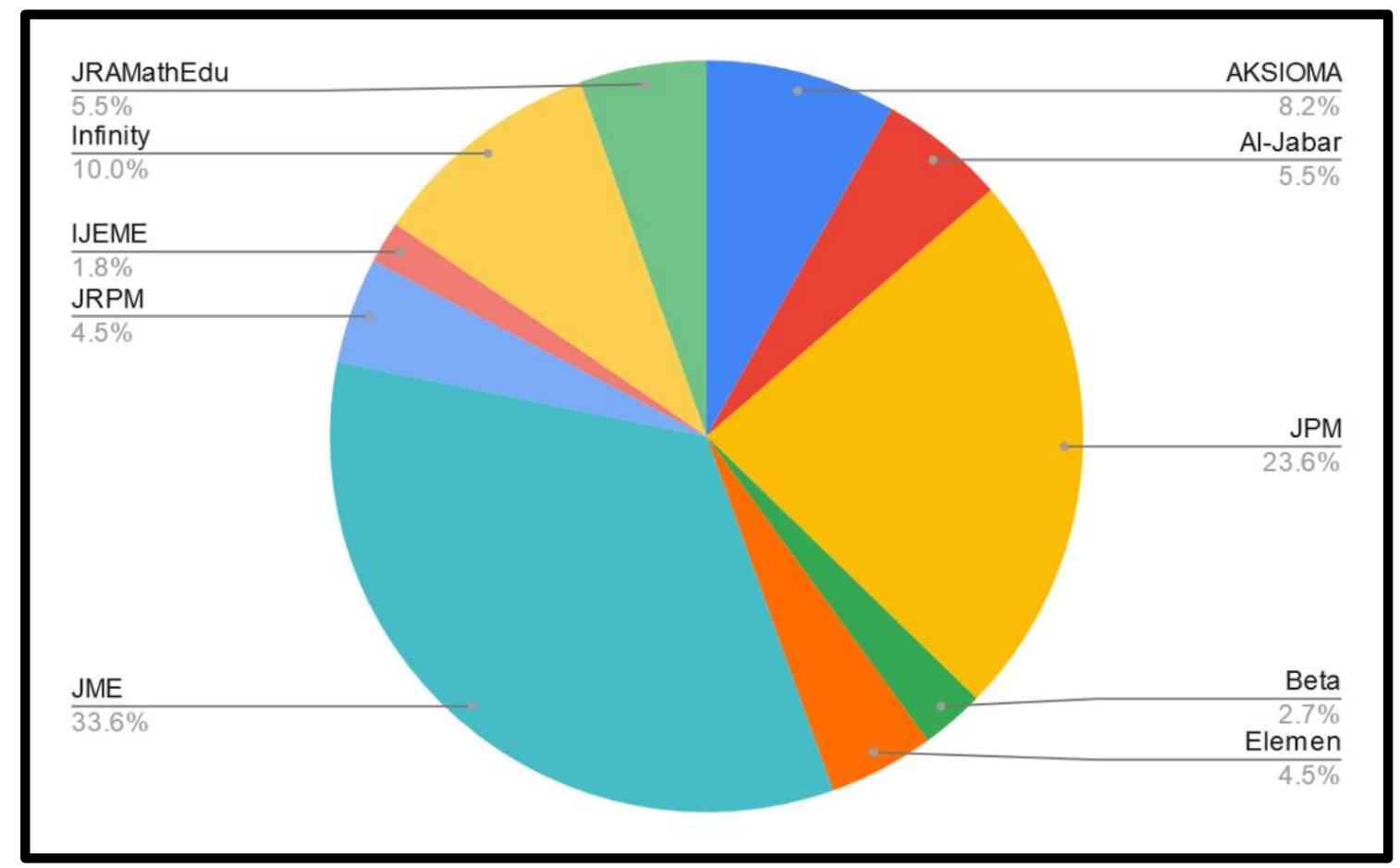

Figure 1. The Number of RME Articles in Each Journal

From all journals that contain RME articles, in general, the focus and scope of each journal are in the fields of education and mathematics education. Based on the information presented on the journal website, there are only four journals that specifically mention RME as one of the focus and scope, including JPM, JME, IJEME, and Infinity.

\subsection{Research Subject on RME Articles in Indonesia}

The momentum for RME research in Indonesia began in 2001 through the experimental learning of six lecturers at the LPTK Higher Education Institutions (Educational Personnel Education Institutions) as an RME team in 12 elementary schools. This was a form of government intervention at that time to make elementary school teachers the spearhead of the expansion of RME in Indonesia as a reform of mathematics learning (Sembiring, 2010). Since then, RME's progress has been continued by providing RME knowledge for LPTK lecturers, especially elementary school teacher candidates. The collaboration is also with universities to establish an International Master's Program on Mathematics education (IMPoME), holding RME workshops with teachers, and continuous dissemination with stakeholders. Based on the history of RME entry into Indonesia, which began with trials at the elementary level, up to two decades of RME in Indonesia, more than $2 / 5 \mathrm{RME}$ research in Indonesia took the subject of elementary school. Slowly but surely, the application of RME is not only at the elementary level. More than $2 / 5$ the application of RME learning at the secondary school level has been carried out, as shown in Figure 2. Expansion of this subject is very likely to occur because the main objective of RME's entry into Indonesia is to bring about fundamental changes in the teaching and learning process of mathematics in Indonesia (Julie, Suwarsono, \& Juniati, 2013), besides that, it is also because the mathematics curriculum in Indonesia at the secondary school level is mostly applied mathematics material. So that the principle of RME as a human activity using a real context 
in learning can be done. The research Subject on RME Articles in Indonesia has shown in Figure 2.

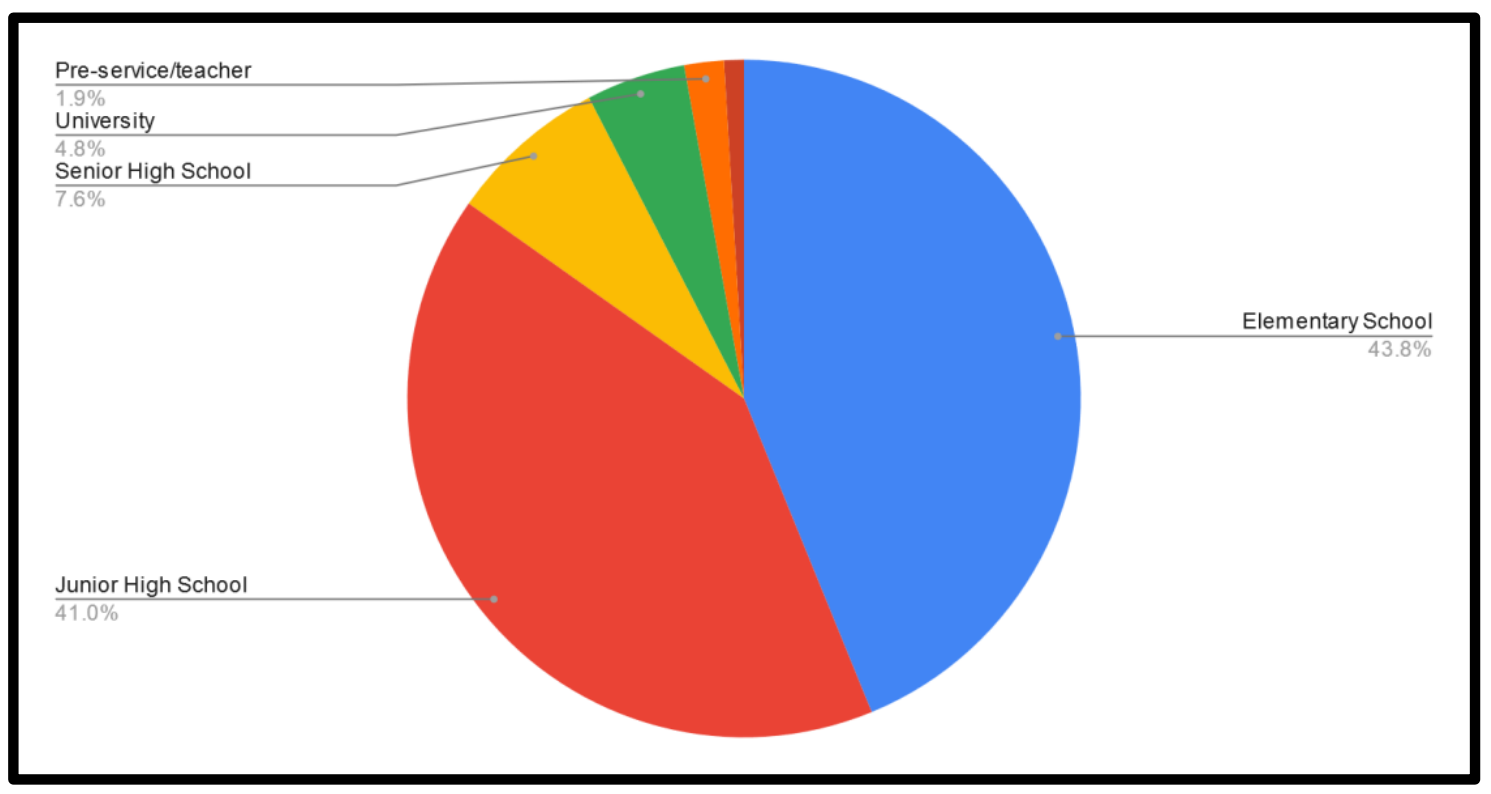

Figure 2. The Research Subject on RME Articles in Indonesia

Figure 2 shows that the most RME research studies were carried out in elementary schools and junior high schools. Almost half of the research was conducted in elementary school, and nearly half of the other research was conducted in junior high school. Studies conducted in senior high school, teachers or pre-service teachers, universities, and others tend to be a little.

The application of RME at the university level is still low, with a proportion of less than $10 \%$ or consisting of 5 well-known publications in three journals, including JME, AlJabar, and AKSIOMA. The small number of RME publications at the university level is interesting for us to discuss. The question that arises is, "can the basic principles of RME developed for elementary school mathematics be adapted for mathematics topics in university?". The answer, indeed, is that RME can be adapted for learning at the university level. Several previous studies have applied RME at the university level, such as Calculus (Kwon, 2002; Rasmussen, Kwon, Allen, Marrongelle, \& Burtch, 2006), Algebra (Larsen, 2013), Geometry (Larsen \& Zandieh, 2008). These studies show that the presentation of problems in mathematics learning at the university level is not only done with textbooks but can be more varied with the interaction model between lecturers and students, as well as the presentation of the problems used by students to learn.

In line with the results of research conducted in the USA, Rasmussen, and King (2000) emphasized that mathematics learning reforms that have been implemented at the primary and secondary school levels can be expanded at the university level. One of the keys is the preparation of a local instructional theory before the lecture process based on the three basic principles of RME according to Gravemeijer (1994) where learning accommodates guided reinvention and progressive mathematizing, didactical phenomenology, and selfdeveloped models (Larsen, 2013; Larsen \& Zandieh, 2008; Rasmussen et al., 2006). Become an opportunity for the development of RME in Indonesia through the expansion of the RME subject at the university level. Thus, the reform of mathematics learning through RME is becoming more extensive and comprehensive. 


\subsection{Mathematical Topic on RME Articles in Indonesia}

Mathematics has many topics or materials that must be studied. However, some of them are quite difficult or cannot be taught using the RME approach. Applied mathematics topic is easier to design on RME learning, which uses 6 principles in RME: activity principle, reality principle, level principle, intertwinement principle, interaction principle, and guidance principle (Van den Heuvel-Panhuizen \& Wijers, 2005). As we know, there are various mathematics topics in schools. Likewise, RME has various topic content.

Based on the analysis of various RME articles in various journals in Indonesia, the topics discussed is quite diverse, including combinatorial, integral, circle equation, ratio, linear equation and inequality, relation and function, equation of two-variable linear, trigonometry, social arithmetic, LCM, GCD, mathematics logic, linear programming, length and time measurement, algebra, 2D Shapes, 3D Shapes, number pattern, decimals, geometry, percentage, set, number, area and perimeter, fractions, integer, speed, table and graphs, time measurement, statistics, reflection, and symmetry, etc. However, we can classify the topic so that it is easier to analyze. At outline, five topic content standards throughout mathematics class are Number and Operations, Algebra, Geometry, Measurement, and Data Analysis and Probability (NCTM, 2000; Walle, Karp, \& Bay-Williams, 2013). The classification of the topic on the topic content standards shown in Figure 3.

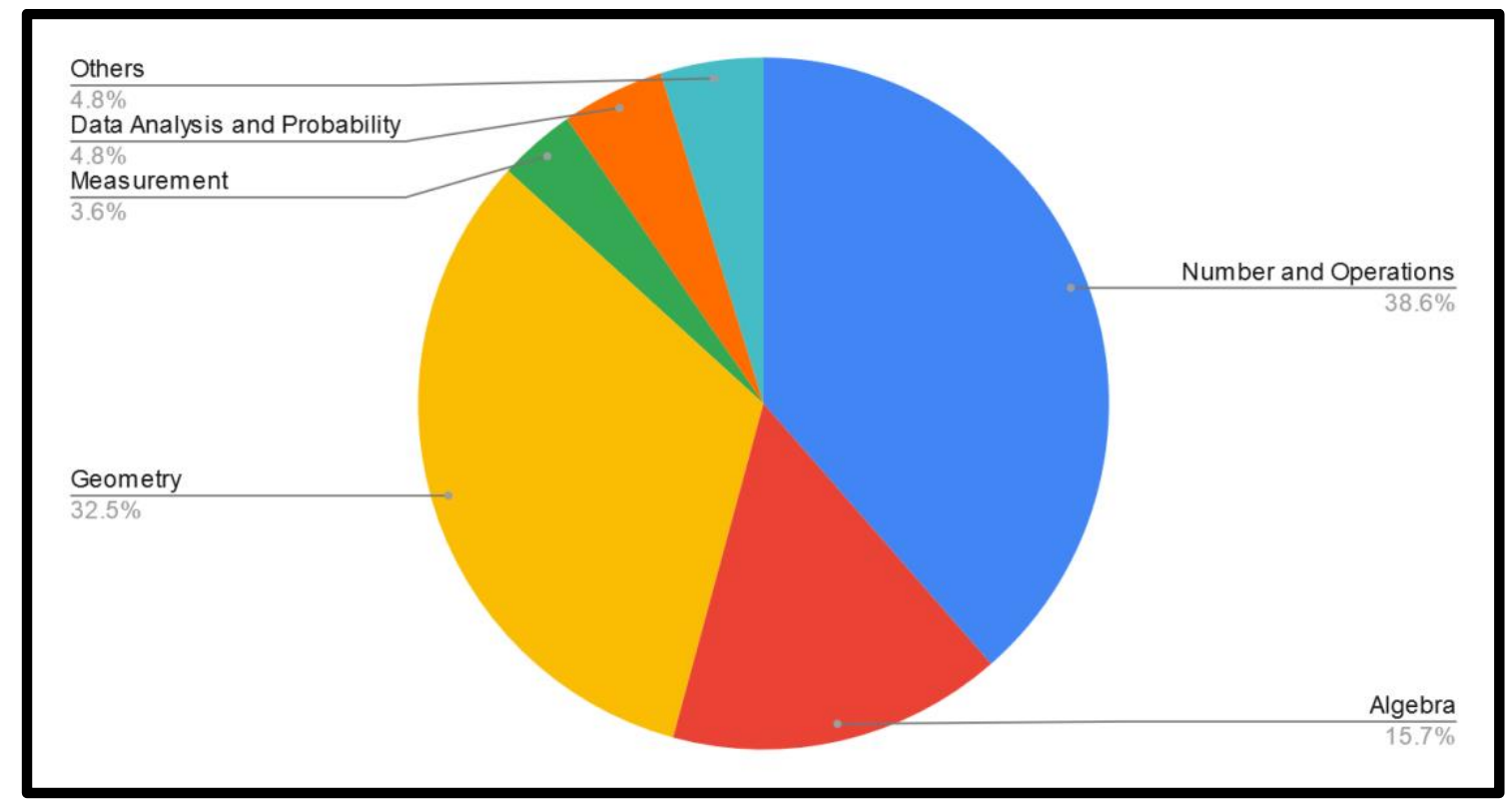

Figure 3. Mathematical Topic in Indonesian Journal of RME

A number of RME research on the topic of "Numbers and operations" are in elementary and junior high schools, not in senior high schools or even universities. The widest research subjects on the Numbers and operations topic are on elementary school students because the Numbers and Operations is the most heavily emphasized strand up to grade 5 (Walle, Karp, \& Bay-Williams, 2013). Hence, Numbers and operations are the most widely discussed in the RME article published in various journals in Indonesia. Nearly $40 \%$ of the topics discussed in the RME articles are Numbers and operations (Figure 3). Coincidentally, we found an RME research on "Numbers and operation" in the JME journal, in which the research subject was not students of elementary or junior high school. However, the research topic material is also related to numbers and operations in elementary schools. 
Meanwhile, Geometry is also widely discussed as material in RME research. Nearly one-third of the material discussed in RME research is geometry (Figure 3). It is because there are a lot of objects around us that contain geometric values that are suitable for use in learning mathematics at an elementary or junior high level. Many research subjects of RME are also in junior high school. Therefore, algebra is on the third-ranks in the number of articles discussing RME on the RME article. Almost one-sixth of all RME articles are about algebra (Figure 3). Algebra heavily emphasized a strong focus in junior and senior high school, and a lesser emphasis in early grades (Walle, Karp, \& Bay-Williams, 2013). Mathematical topics on Data Analysis and Probability, Measurement, and others (integral, trigonometry, mathematics logic) are rarely discussed in the RME research.

\subsection{Mathematics Ability on RME Articles in Indonesia}

The goals of the research on mathematics education have various types of mathematical abilities. There are many categories on it, i.e. Taxonomy Bloom: Remembering, Understanding, Applying, Analyzing, Evaluating, and Creating (Bloom, 1956); Problem Solving, Reasoning \& Proof, Communication, Connections, Representation (NCTM, 2000); etc.

This paper categorizes the goal of the research on RME as mathematics ability and non-mathematics ability based on Taxonomy Bloom and NCTM. Mathematics abilities are mathematical abilities obtained in learning with RME and non-mathematics abilities, namely attitudes or abilities that are not mathematical abilities. Mathematics ability is divided into 11 parts: mathematical understanding, communication, connections, representation, reasoning and proof, mathematical literacy, critical thinking, creative thinking, problemsolving, disposition, and intuitive skills. Furthermore, non-mathematics ability consists of eight items: character, student activities, learning independence, self-efficacy, student performance, learning interest, achievement, and intrapersonal intelligence. The categories created to position mathematics ability in various RME articles are presented in Figure 4.

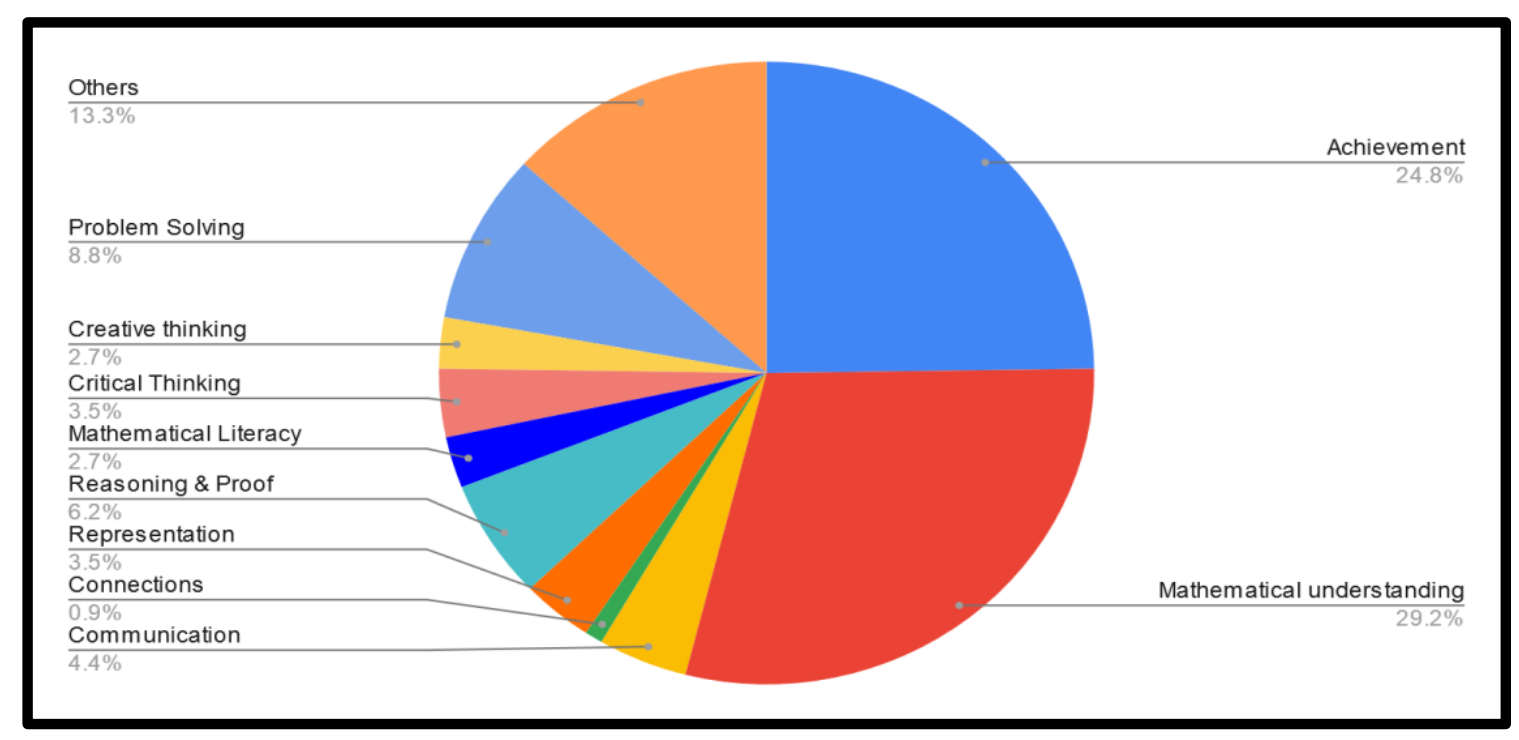

Figure 4. The Categories of Mathematics Ability on RME Articles

RME research related to mathematical understanding amounted to more than $1 / 4$ of the total sample used, $1 / 4$ the rest was mostly on communication skills, and problem-solving was in the third-largest order (Figure 4). Revina and Leung (2018) explain that the goal of 
learning mathematics in the curriculum in Indonesia is to equip students with mathematical understanding skills and to develop communication and problem-solving. This is a reference for researchers to conduct research in achieving the goals of the Indonesian curriculum.

If we analyze more deeply, the topic of mathematical understanding used by researchers is mostly in the number and operations group of material; the rest is on measurement and geometry with a small portion. It is presented in Figure 3, where numbers and operations are the most material used as RME research topics in the last two decades. Nursyahidah, Putri, and Somakim (2013) explained that the number and operations material is one of the prerequisite knowledges for learning mathematics on other topics. So that students must have the correct and robust concept on number and operations material.

In addition to mathematical understanding and other mathematical skills, as in Figure 4, the author performs another grouping using the term "others." In this group, several researchers conducted research by looking for the impact of RME learning on students. Such as student character (Palinussa, 2013), student personality (Kowiyah, Mulyawati, \& Umam, 2019; Amin, 2007), gender (Hasratuddin, 2010), and students' intuitive abilities (Hirza et al., 2014). For example, research on the four personality types of students after participating in RME learning found students with rational personality types were very good at identifying and making examples, traits, and conditions. Students with idealistic personality types are very good at identifying verbally and in written form. The conceptual understanding of the four personality types when identifying and differentiating concepts is still weak. Meanwhile, for the aspect of mathematical representation, the four personality types are excellent in visual, accurate representation in the form of numbers and tables. There is an opportunity for future RME research to follow up on the results of the classifications that have been made by these researchers, namely, by designing an RME lesson that is tailored based on student character, student personality, gender, and student cognitive level.

\subsection{Various Terms Used on RME Articles in Indonesia}

The adoption of RME in Indonesia conducted in various studies refers to the Netherlands. However, the use of the term at RME in Indonesia is varied, starting from using the original term "RME" and using another term, i.e. Pendidikan Matematika Realistik Indonesia (PMRI), Pendidikan Matematika Realistik (PMR), Indonesian Mathematics Realistic Education (IRME), and Realistic, Educational, Contextual, Cognitive, and Evaluation (RECCE). Variations of the terms used in various articles can be seen in the Figure 5.

The term most commonly used is the original term, RME, and the least used is the term RECCE. The term which is widely used, namely PMRI and PMR, occupies an almost similar position. The term RME has become very popular in publications in Indonesia, where nearly half of the 110 samples used in this article come from eight journals. This is commonplace if most authors choose to use the term RME because this term is commonly used throughout the world. Zulkardi et al. (2020) use an alternate term between RME and PMRI in an article entitled "Two Decade of Realistic Mathematics Education," depending on the setting of the story being used.

Another term that is also used in almost a quarter of the part is PMR. This term first appeared in 2010 through the writings of Sugiman and Kusumah (2010). Despite the different terms used, these 20 articles refer to the definitions and principles of RME. This can be seen from the reference sources used mostly come from the theory of Gravemeijer. Another small section of the article uses the term IRME which is the English equivalent or modification of PMRI. Two authors, namely Assiti, Zulkardi, and Darmawijoyo (2013), as 
well as Risdiyanti and Prahmana (2020), have previously emphasized that the term IRME used is the adoption of RME both the definition and principle used.

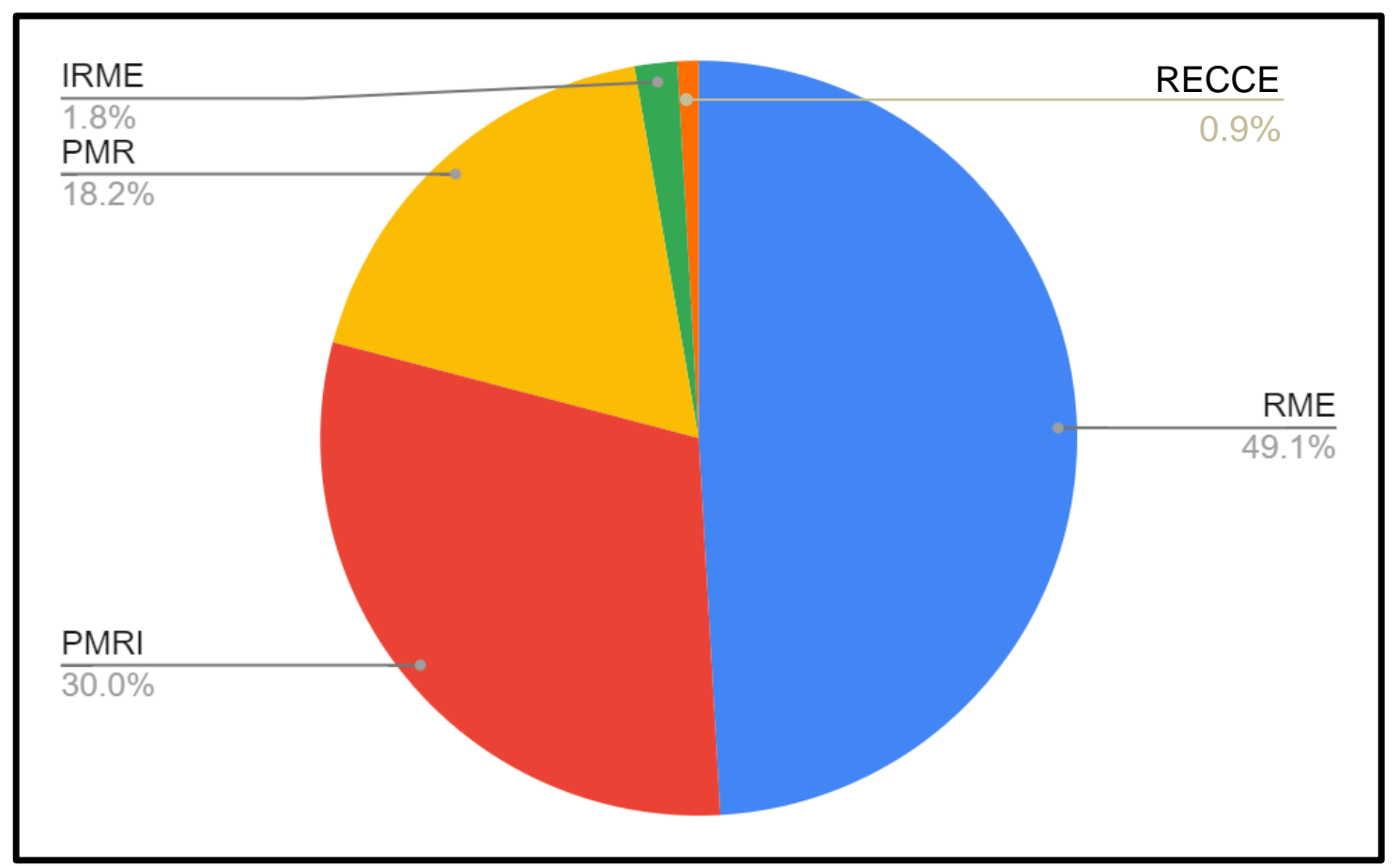

Figure 5. Variations of the Terms of "RME" on RME Articles

The interesting thing from the analysis of the term RME used in 10 sample journals is the emergence of the term RECCE published in JME by Chong, Shahrill, and Li (2019) and only one of the entire samples. As shown in Figure 5, it becomes a tiny part of the orange. This framework was created and given the term "RECCE-MODEL," which emphasizes understanding and thinking with a view of mathematics embedded in real life. "RECCE," which stands for Realistic, Educational, Contextual, Cognitive, and Evaluation. This framework includes the principles underlying mathematics learning through activities that use real-life in developing students' problem-solving competencies. Seeing this phenomenon, it is possible that in the future, there will be a development of an approach or model that adopts the RME principle so that other terms will appear. For example, the terms for RME that are online based, RME based on culture, or RME for children with special needs.

\subsection{Research Methods on RME Articles in Indonesia}

The articles on RME in 10 sample journals were mostly the result of research with various methods. The research methods used include literature review, design research, Experiment, Classroom Action Research (CAR), Causal-Comparative research, Research and Development (RnD), Mix Method, and Descriptive Qualitative.

The data shows that more than a quarter of the RME research uses the design research method. Almost all sample journals have articles with the design research method except JRPM, Al-Jabar, and axioms. Research with the Design research method is $71 \%$ in the JME journal, about $10 \%$ of design research articles at JPM, and the rest is in other journals. The second-largest research method used by RME researchers is the experimental method. The number of articles that contain experimental methods in the JME journal and in JPM is the 
same, namely about $23 \%$, respectively. Other journals that contain articles on RME with innovative methods are JRPM, Al-Jabar, JRAMathEdu, and AKSIOMA, which are about $7 \%$ each, and Element around 3\%. In other words, almost all journals contain RME with experimental methods, except IJEME and Beta journals. The third-largest research method used by researchers is Research and Development $(\mathrm{RnD})$. Research with the $\mathrm{RnD}$ method is mostly at JPM. There are 50\% of articles with the RnD method in JPM. AXIOMA also has a lot of RnD research methods, which is around 30\%, while the rest are in JRPM, Al-Jabar, and JRAMathEdu. Another research method used is descriptive qualitative. Qualitative descriptive methods are present in almost all journals, except IJEME and axioms. Apart from these various methods, other research methods are prevalent and not widely used in RME research. For example, Classroom action research methods only exist in Beta, Element, and JPM, respectively 1. Meanwhile, comparative causal research and mix methods occupy a minority position.

There are not many RME articles in various journals in Indonesia that use these two methods. Based on the analysis, the dominant research methods of the articles from all journals that contain RME articles use design research, followed by experiment, research and development, and descriptive qualitative. The rarely used research methods are causalcomparative research and mix methods between quantitative and qualitative research. Of all the research methods used in the RME article in Indonesia can be seen in Figure 6.

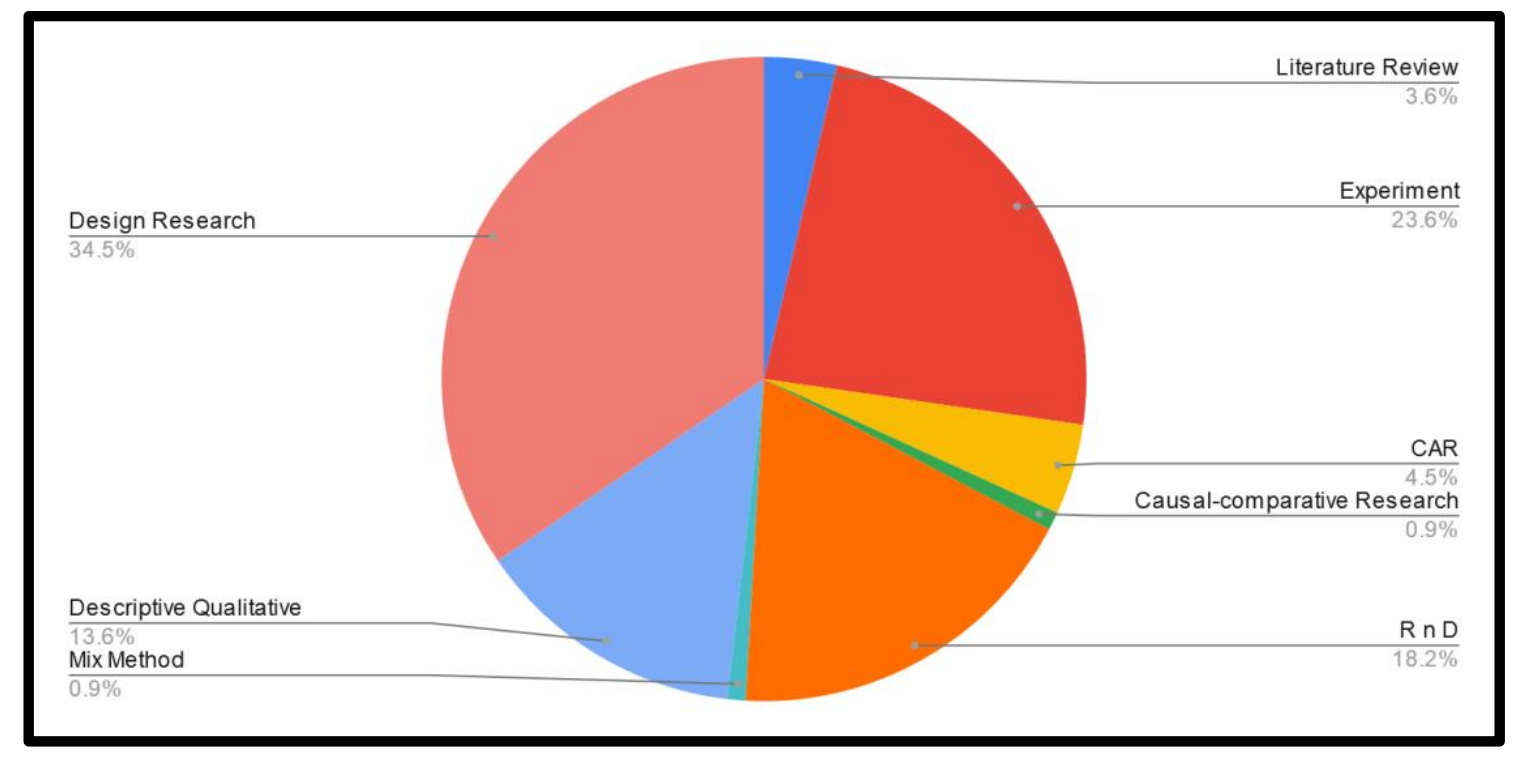

Figure 6. The Research Methods on RME Articles in Indonesia

Although design research dominates RME research for up to two decades of RME in Indonesia, the author predicts that research with the RME research design method will still be in demand by RME researchers. Based on the opinion of Van den Heuvel-Panhuizen and Drijvers (2020a) that a teacher must have a proactive role in preparing RME learning scenarios and designs. Through design, research will produce a local instruction theory in the learning process. The process of finding the theory of local instruction is long and continuous, even with the same material. 


\subsection{RME Research Paper in Indonesia in the Last Two Decades}

The question posed by Zulkardi, Putri, and Wijaya (2020) in two decades of RME in Indonesia is, "Is PMRI still alive in mathematics education in Indonesia?" In his paper, Zulkardi explained about the untold story of the development of RME in Indonesia for two decades. Table 1 is a classification based on the subject level starting from elementary school, junior high school, senior high school, undergraduate, and others for those not included in formal education. The data presented in Table 1 generally answer this question, that RME in Indonesia is still alive, this can be seen from the number of RME publications scattered in ten journals that are accredited by the Ministry of Research, Technology and Higher Education, which varies greatly from a subject, topic, term, and method used. JPM, JME, IJEME, and Infinity are journals that consistently produce publications with one focus and scope on RME. Publications in journals are proof that RME activities as an innovation in mathematics learning are still ongoing. Journals can be used as a medium for stakeholders such as teachers, lecturers, students, students, teacher educators, researchers, and book writers to accept and share their findings.

The next question in Zulkardi, Putri, and Wijaya (2020) are "what are the activities or developments of PMRI currently?". This article found the distribution of RME subjects that did not exist in previous years. Research conducted by Risdiyanti and Prahmana (2020) at the Yogyakarta Mathematics Study Club (YMSC), a club consisting of several mathematics education graduates who are involved in innovating mathematics learning.

Another point of view, the researcher found the background of conducting research on mathematical understanding, including the learning process at the primary and secondary school levels still using conventional teacher-centered learning and the delivery of material that is too formal (Pramudiani, Zulkardi, Hartono, \& Amerom, 2011; Kesumawati, 2015; Zabeta, Hartono, \& Putri, 2015; Nursyahidah, Putri, \& Somakim, 2013, Sari, Juniati, \& Patahudin, 2012; Rifandi, 2016), the learning process of mathematics is not sufficient to help develop students' mathematical thinking (Anwar, Budayasa, Amin, \& De Haan, 2012; Lismareni, Somakim, \& Kesumawati, 2015), learning is less meaningful and focuses on procedures (Khairunnisak, Maghfirotun, Juniati, \& De Haan, 2012), tends to focus on procedures (Rianasari, Budayasa, \& Patahuddin, 2012). With the learning process that has occurred so far, students do not understand the concept of numbers and operations (Rianasari et al., 2012; Nursyahidah et al., 2013; Julie et al., 2013), students' understanding of the concept of prism volume material is still lacking. (Fadlilah, 2014), and students do not have individual readiness to understand the concept in depth (Sari, 2014).

In the last two decades, more than $1 / 4$ of the RME research is design research. More than $1 / 2$ of the design research is the material number and operation. The more so is the material on algebra, Data Analysis, and Probability, and measurement, each with the same amount. These materials are dominated by material at the elementary level. Products from development research produce RME learning tools including teachers and students manual books (Diba, Zulkardi, \& Saleh, 2009), teaching materials (Misdalina, Zulkardi, \& Purwoko, 2009; Fuadiah, Zulkardi, \& Hiltrimartin, 2009; Taufik, Zulkardi, \& Somakim, 2012; Syutaridho, Zulkardi, \& Hartono, 2012; Simanulang, 2014), student worksheet (Komsiatun, 2018; Wewe \& Juliawan, 2019), assessment (Rahayu, Purwoko, \& Zulkardi, 2008; Utami, \& Nirawati, 2018 ), IT-based media (Wahyuni, Masykur, \& Pratiwi, 2019; Pratama, Yahya, $\&$ Pratiwi, 2019). The RME experimentation shows the effectiveness of learning using RME compared to conventional, CTL, scientific, and expository learning. Several researchers used the one-group experimental method, including testing the implementation of Realistic Mathematics Education using Geometer's Sketchpad (Dhayanti, Johar, \& Zubainur, 2018), implementing RME based on Adobe Flash Professional CS6 (Umbara \& Nuraeni, 2019). 
Lastly, Table 1 summarizes the grouping of sample articles in this paper based on the mathematical content topic by subject level. Therefore, we hope that this table could be used as a guide to examine the distribution of RME studies over the two decades in Indonesia by researchers.

Table 1. Resume of RME Research Paper in Indonesia

\begin{tabular}{|c|c|c|c|}
\hline No & Level & $\begin{array}{l}\text { Mathematical } \\
\text { Content Topic }\end{array}$ & References \\
\hline \multirow[t]{5}{*}{1} & Elementary & Algebra & $\begin{array}{l}\text { (Jupri et al., 2020; Apsari et al., 2000; Nursyahidah, } \\
\text { Saputro, \& Rubowo, 2018; Lestariningsih et al., } \\
\text { 2015; Assiti et al., 2013; Dhayanti et al., 2018) }\end{array}$ \\
\hline & & Geometry & $\begin{array}{l}\text { (Komsiatun, 2018; Fuadiah et al., 2009; Taufik et } \\
\text { al., 2012; Syutaridho et al., 2012; Alkusaeri, 2014; } \\
\text { Palupi, 2017; Rizkianto et al., 2013; Winarti et al., } \\
\text { 2012; Yuberta et al., 2011; Haris \& Ilma, 2011; } \\
\text { Alriavindrafunny, 2014; Wewe \& Juliawan, 2019; } \\
\text { Helsa \& Hartono, 2001) }\end{array}$ \\
\hline & & Measurement & $\begin{array}{l}\text { (Amin, 2007, Jaelani et al., 2013; Khikmiyah et al., } \\
\text { 2012) }\end{array}$ \\
\hline & & $\begin{array}{l}\text { Number and } \\
\text { Operation }\end{array}$ & $\begin{array}{l}\text { Muncarno \& Astuti, 2018; Afriyansyah \& Putri, } \\
\text { 2013; Edo et al., 2015; Johar et al., 2016; } \\
\text { Yusmanita et al 2018; Julie et al., 2013, } \\
\text { Nursyahidah et al., 2013; Murdiyani et al., 2013; } \\
\text { Triyani } \text { et al., 2012, Khairunnisak et al, 2012; Sari } \\
\text { et al., 2012; Anwar et al., 2012; Rianasari et al., } \\
\text { 2012; Shanty et al., 2011; Pramudiani et al., 2011; } \\
\text { Putra et al., 2011; Astuti, 2014; Shanty, 2016; } \\
\text { Nasution } \text { et al., 2018; Saleh } \text { et al., 2018; Ardiyani } \\
\text { et all., 2018; Putri \& Zulkardi, 2019; Rifandi, 2016; } \\
\text { Diba et al., 2009) }\end{array}$ \\
\hline & & Others & $\begin{array}{l}\text { (Zulkardi \& Ilma, 2010; Hirza, Kusumah, Darhim, } \\
\text { \& Zulkardi, 2014; Haji, Yumiati, \& Zamzaili, } \\
\text { 2019) }\end{array}$ \\
\hline \multirow[t]{2}{*}{2} & $\begin{array}{l}\text { Junior High } \\
\text { School }\end{array}$ & Algebra & $\begin{array}{l}\text { (Septianawati, 2014; Wahyuni et al., 2019; Sulastri } \\
\text { et al., 2017; Kusumaningsih et al., 2018; Nuraida } \\
\text { \& Amam, 2019; Simanullang, 2013) }\end{array}$ \\
\hline & & $\begin{array}{l}\text { Data analysis } \\
\text { and Probability }\end{array}$ & $\begin{array}{l}\text { (Putria et al., 2015; Muttaqin et al., 2017; Sari, } \\
\text { 2014) }\end{array}$ \\
\hline
\end{tabular}




\begin{tabular}{|c|c|c|c|}
\hline No & Level & $\begin{array}{l}\text { Mathematical } \\
\text { Content Topic }\end{array}$ & References \\
\hline & & Geometry & $\begin{array}{l}\text { (Utami \& Nirawati, 2018; Putra, 2016; Fadlilah, } \\
\text { 2014; Yunisha et al., 2016; Maisyarah \& } \\
\text { Prahmana, 2020; Sari, 2016; Nurdiansyah \& } \\
\text { Prahmana, 2017; Haji \& Abdullah, 2015; } \\
\text { Khaerunisak et al., 2017; Fitriani et al., 2018; } \\
\text { Fahrurozi et al., 2018; Rahayu et al., 2008; } \\
\text { Farhatin, 2012) }\end{array}$ \\
\hline & & $\begin{array}{l}\text { Number and } \\
\text { Operation }\end{array}$ & $\begin{array}{l}\text { (Sari \& Sari, 2019; Rahmawati \& Amah, 2018; } \\
\text { Simanulang et al., 2013; Lismareni et al., 2015; } \\
\text { Zabeta et al., 2015; Meryansumayeka et al., 2011; } \\
\text { Saleh \& Isa, 2015; Suherman, 2015) }\end{array}$ \\
\hline & & Others & $\begin{array}{l}\text { (Paradita, Vahlia \& ES, 2019; Hasratuddin, 2010; } \\
\text { Kesumawati, 2014, 2015; Palinussa, 2013; } \\
\text { Sugiman \& Kusumah, 2010; Abdurahim, 2016; } \\
\text { Wibowo, 2017; Habsah, 2017; Haji \& Abdullah, } \\
\text { 2016; Herawaty \& Rusdi, 2016; Muhtarom, } \\
\text { Nizaruddin, Nursyahidah \& Happy, 2019; Umbara } \\
\text { \& Nuraeni, 2019) }\end{array}$ \\
\hline \multirow[t]{4}{*}{3} & Senior High & Geometry & (Dwijayani, 2018; Krismiati, 2013) \\
\hline & & Algebra & (Hidayat \& Iksan, 2015; Niswarni, 2012) \\
\hline & & $\begin{array}{l}\text { Data analysis } \\
\text { and Probability }\end{array}$ & (Meika et al., 2019) \\
\hline & & Others & $\begin{array}{l}\text { (Zulkardi, 2019; Budi, 2008, Chong, Shahrill \& Li, } \\
\text { 2019) }\end{array}$ \\
\hline \multirow[t]{2}{*}{4} & Undergraduate & Geometry & (Kowiyah et al., 2019) \\
\hline & & Others & $\begin{array}{l}\text { (Pratama et al., 2019; Farida et al., 2019, Julie et } \\
\text { al., 2013, 2014; Yilmaz, 2020) }\end{array}$ \\
\hline \multirow[t]{2}{*}{5} & Others & $\begin{array}{l}\text { Number and } \\
\text { operations }\end{array}$ & (Risdiyanti \& Prahmana, 2020) \\
\hline & & Others & (Setyaningsih et al., 2019) \\
\hline
\end{tabular}

\section{CONCLUSION}

We have summarized 110 papers displayed in Table 1 and categories the published RME articles on seven categories, i.e. the dominance of published RME articles, RME research subjects, mathematical topics, students' abilities, RME terms, and the research 
method used in RME articles. RME was adopted from the Netherlands, so the most used term is "RME," which is the original term, followed by PMRI. On the other hand, most articles were in the JME and followed by the JPM, with the most widely used design research method.

The most topic of RME material studied is numbers and operations, followed by geometry. It is an elementary level of school mathematics. Hence, RME research is mostly in elementary schools and followed by junior high schools. We encourage RME researchers to conduct the study at other levels, such as higher education. The mathematics materials using RME is needed to be more diverse and comprehensive, not only on early levels or elementary students but also on the advanced level mathematics subject.

Moreover, most of the mathematics ability in RME research is mathematical understanding, followed by mathematics achievement. Whereas based on the characteristics of PMRI, it is not only mathematical understanding or achievement but also many other mathematical abilities that can be developed. Therefore, we encourage the RME researchers to study the effect of RME on different mathematics abilities. Furthermore, RME researchers not only can research mathematics abilities but also include affective abilities.

Overall, we encourage the community on the teaching and learning of mathematical modeling and applications to submit their papers more often to high impact journals, to improve the visibility of modeling in the mathematics education community. Furthermore, more quantitatively oriented studies seem to be necessary for the future teacher to come to more general results on the effects of teaching and learn mathematical modeling, focusing on cognitive aspects and including significant elements.

\section{ACKNOWLEDGEMENTS}

The author would like to all authors whose papers are cited in this paper as a valuable reference and resource for this paper. Furthermore, thanks to all reviewers for their helpful feedback.

\section{REFERENCES}

Abdurahim, A. (2016). Keefektifan model pembelajaran resik ditinjau dari sikap, motivasi, dan kemampuan berpikir kritis matematis siswa SMP. Jurnal Riset Pendidikan Matematika, 3(2), 137-149. https://doi.org/10.21831/jrpm.v3i2.7994

Afriyansyah, E. A., \& Putri, R. I. I. (2014). Design research: Konsep nilai tempat pada operasi penjumlahan bilangan desimal di kelas V sekolah dasar. Jurnal Pendidikan Matematika, 8(1), 13-24. http://dx.doi.org/10.22342/jpm.8.1.1857.13-24

Alkusaeri, A. (2014). Peningkatan keefektifan pembelajaran matematika melalui pendekatan realistik. Beta: Jurnal Tadris Matematika, 7(1), 13-24.

Alriavindrafunny, R. (2014). Students' initial understanding of the concept of conservation of area. Journal on Mathematics Education, 5(1), 57-65. https://doi.org/10.22342/jme.5.1.1449.57-65

Amin, S. (2007). Pembelajaran matematika yang melibatkan kecerdasan intrapribadi dan interpribadi. Jurnal Pendidikan Matematika, 1(2), 11-21. https://doi.org/10.22342/jpm.1.2.809.

Anwar, L., Budayasa, I. K., Amin, S. M., \& De Haan, D. (2012). Eliciting mathematical thinking of students through realistic mathematics education. Journal on Mathematics Education, 3(1), 55-70. https://doi.org/10.22342/jme.3.1.620.55-70 
Apsari, R. A., Putri, R. I. I., Sariyasa, Abels, M., \& Prayitno, S. (2020). Geometry representation to develop algebraic thinking: A recommendation for a pattern investigation in pre-algebra class. Journal on Mathematics Education, 11(1), 45-58. https://doi.org/10.22342/jme.11.1.9535.45-58

Ardiyani, S. M., \& Gunarhadi, R. (2018). Realistic mathematics education in cooperative learning viewed from learning activity. Journal on Mathematics Education, 9(2), 301-310. https://doi.org/10.22342/jme.9.2.5392.301-310

Assiti, S. S., Zulkardi, \& Darmawijoyo, D. (2013). Set a Structure of Objects with a Help of Grouping to Ten Strategy to Understand the Idea of Unitizing. Journal on Mathematics Education, 4(2), 204-211. https://doi.org/10.22342/jme.4.2.556.204211

Astuti, P. (2014). Learning one-digit decimal numbers by measurement and game predicting length. Journal on Mathematics Education, 5(1), 35-46. https://doi.org/10.22342/jme.5.1.1447.35-46

Bloom, B. S. (1956). Taxonomy of educational objectives. Vol. 1: Cognitive domain. New York: McKay, 20, 24

Budi, R. R. S. (2008). Penerapan Pendidikan Matematika Realistik Indonesia melalui penggunaan alat peraga praktik miniatur tandon air terhadap hasil belajar siswa di kelas X SMA Negeri 3 Kota Manna. Jurnal Pendidikan Matematika, 2(1), 63-80. https://doi.org/10.22342/jpm.2.1.299.

Chong, M. S. F., Shahrill, M., \& Li, H. C. (2019). The integration of a problem-solving framework for Brunei high school mathematics curriculum in increasing student's affective competency. Journal on Mathematics Education, 10(2), 215-228. https://doi.org/10.22342/jme.10.2.7265.215-228

Dhayanti, D., Johar, R., \& Zubainur, C. M. (2018). Improving students' critical and creative thinking through realistic mathematics education using geometer's sketchpad. JRAMathEdu (Journal of Research and Advances in Mathematics Education), 3(1), 25-35. https://doi.org/10.23917/jramathedu.v3i1.5618

Diba, F., Zulkardi, \& Saleh, T. (2009). Pengembangan materi pembelajaran bilangan berdasarkan Pendidikan Matematika Realistik untuk siswa kelas V Sekolah Dasar. Jurnal Pendidikan Matematika, 3(1), 33-46. https://doi.org/10.22342/jpm.3.1.319.

Dwijayani, N. M. (2018). Pembelajaran lingkaran berbantuan permasalahan matematika realistik untuk meningkatkan kemampuan pemecahan masalah siswa. AKSIOMA: Jurnal Program Studi Pendidikan Matematika, 7(1), 34-47. http://dx.doi.org/10.24127/ajpm.v7i1.1249

Edo, S. I., Tanghamap, K., \& Tasik, W. F. (2015). Model pembelajaran penjumlahan dan pengurangan bilangan melalui pendekatan pmri konteks permainan karet gelang. Jurnal Pendidikan Matematika, 9(2), 99-123. http://dx.doi.org/10.22342/jpm.9.2.2428.99-123

Fadlilah, N. (2014). Pemahaman konsep siswa pada materi volume prisma dengan Pendekatan Pendidikan Matematika Realistik Indonesia (PMRI). Jurnal Pendidikan Matematika, 8(2), 20-32. http://dx.doi.org/10.22342/jpm.8.2.1864.20-32

Fahrurozi, A., Maesaroh, S., Suwanto, I., \& Nursyahidah, F. (2018). Developing learning 
trajectory based instruction of the congruence for ninth grade using central java historical building. JRAMathEdu (Journal of Research and Advances in Mathematics Education), 3(2), 78-85. https://doi.org/10.23917/jramathedu.v3i2.6616

Farhatin, D. (2012). Pembelajaran materi luas permukaan balok dan kubus dengan pendekatan Contextual Teaching and Learning (CTL). Jurnal Pendidikan Matematika, 6(2), 45-53. https://doi.org/10.22342/jpm.6.2.4087.45-53

Farida, F., Hartatiana, H., \& Joemsittiprasert, W. (2019). The use of Realistic Mathematics Education (RME) in improving mathematical analogical ability and habits of mind. Al-Jabar: Jurnal Pendidikan Matematika, 10(2), 175-186. https://doi.org/10.24042/ajpm.v10i2.3540

Fitriani, N., Suryadi, D., \& Darhim. (2018). The students' mathematical abstraction ability through realistic mathematics education with vba-microsoft excel. Infinity Journal, 7(2), 123-132. https://doi.org/10.22460/infinity.v7i2.p123-132

Fuadiah, N. F., Zulkardi, \& Hiltrimartin, C. (2009). Pengembangan Perangkat Pembelajaran pada Materi Geometri dan Pengukuran dengan Pendekatan Pendidikan Matematika Realistik Indonesia di SD Negeri 179 Palembang. Jurnal Pendidikan Matematika, 3(2), 74-84. https://doi.org/10.22342/jpm.3.2.329.

Gravemeijer, K. P. E. (1994). Developing Realistic Mathematics Education. Utrecht: Freudenthal Institute.

Gravemeijer, K., \& Doorman, M. Context Problems in Realistic Mathematics Education: A Calculus Course as an Example. Educational Studies in Mathematics, 39, 111-129 (1999). https://doi.org/10.1023/A:1003749919816

Habsah, F. (2017). Developing teaching material based on realistic mathematics and oriented to the mathematical reasoning and mathematical communication. Jurnal Riset Pendidikan Matematika, 4(1), 43-55. https://doi.org/10.21831/jrpm.v4i1.10199

Haji, S., \& Abdullah, M. I. (2015). Membangun kemandirian belajar siswa melalui pembelajaran matematika realistik. Infinity Journal, 4(1), 39-46. https://doi.org/10.22460/infinity.v4i1.p39-46

Haji, S., \& Abdullah, M. I. (2016). Peningkatan kemampuan komunikasi matematik melalui pembelajaran matematika realistik. Infinity Journal, 5(1), 42-49. https://doi.org/10.22460/infinity.v5i1.p42-49

Haji, S., Yumiati, Y., \& Zamzaili, Z. (2019). Improving Students' productive disposition through realistic mathematics education with outdoor approach. JRAMathEdu (Journal of Research and Advances in Mathematics Education), 4(2), 101-111. https://doi.org/10.23917/jramathedu.v4i2.8385

Haris, D., \& Putri, R. I. I. (2011). The role of context in third graders' learning of area measurement. Journal on Mathematics Education, 2(1), 55-66. https://doi.org/10.22342/jme.2.1.778.55-66

Hasratuddin, H. (2010). Meningkatkan kemampuan berpikir kritis siswa smp melalui Pendekatan Matematika Realistik. Jurnal Pendidikan Matematika, 4(2), 20-33. https://doi.org/10.22342/jpm.4.2.317.

Helsa, Y., \& Hartono, Y. (2001). Designing reflection and symmetry learning by using math traditional dance in primary school. Journal on Mathematics Education, 7(1), 79-94. https://doi.org/10.1080/13504620020023480 
Herawaty, D., \& Rusdi, R. (2016). Increased capacity of the understanding of the concept and the ability to solve problems through the implementation of the model of teaching mathematics realistic based on cognitive conflict students. Infinity Journal, 5(2), 109-120. https://doi.org/10.22460/infinity.v5i2.p109-120

Hidayat, R., \& Iksan, Z. (2015). Miskonsepsi pada topik program linear siswa Sekolah Menengah. Jurnal Pendidikan Matematika, 9(1), http://dx.doi.org/10.22342/jpm.9.1.2090.11-21

Hirza, B., Kusumah, Y. S., Darhim, \& Zulkardi. (2014). Improving intuition skills with realistic mathematics education. Journal on Mathematics Education, 5(1), 27-34. https://doi.org/10.22342/jme.5.1.1446.27-34

Jaelani, A., Putri, R. I. I., \& Hartono, Y. (2013). Students' strategies of measuring time using traditional "gasing" game in third grade of primary school. Journal on Mathematics Education, 4(1), 29-40. https://doi.org/10.22342/jme.4.1.560.29-40

Johar, R., Zubaidah, T., \& Mariana, N. (2016). Upaya guru mengembangkan karakter siswa melalui pembelajaran matematika dengan pendekatan realistik pada materi perkalian. Jurnal Pendidikan Matematika Sriwijaya, 10(1), 96113. http://dx.doi.org/10.22342/jpm.10.1.3286.96-113

Julie, H., Suwarsono, S., \& Juniati, D. (2013). The first cycle of developing teaching materials for fractions in grade five using realistic mathematics education. Journal on Mathematics Education, 4(2), 172-187. https://doi.org/10.22342/jme.4.2.415.172-187

Julie, H., Suwarsono, S., \& Juniati, D. (2014). Understanding profile from the philosophy, principles, and characteristics of RME. Journal on Mathematics Education, 5(2), 148-159. https://doi.org/10.22342/jme.5.2.1499.148-159

Jupri, A., Usdiyana, D., \& Sispiyati, R. (2020). Peran representasi matematis dalam pembelajaran perkalian bentuk aljabar melalui pendekatan matematika realistik. Jurnal Elemen, 6(1), 89-98. https://doi.org/10.29408/jel.v6i1.1716

Kesumawati, N. (2014). Meningkatkan kemampuan pemahaman matematis siswa SMP melalui pendekatan Pendidikan Matematika Realistik Indonesia (PMRI). Jurnal Pendidikan Matematika, 6(2), 30-44. https://doi.org/10.22342/jpm.6.2.4086.30-44

Kesumawati, N. (2015). Meningkatkan kemampuan pemahaman matematis siswa smp melalui pendekatan Pendidikan Matematika Realistik Indonesia (PMRI). Jurnal Pendidikan Matematika, 8(2), 1-19. https://doi.org/10.22342/jpm.8.2.1911.57-75

Khaerunisak, K., Kartono, K., Hidayah, I., \& Fahmi, A. Y. (2017). The analysis of diagnostic assessment result in PISA mathematical literacy based on students self-efficacy in RME learning. Infinity Journal, 6(1), 77-94. https://doi.org/10.22460/infinity.v6i1.p77-94

Khairunnisak, C., Maghfirotun, S., Juniati, A. D., \& De Haan, D. (2012). Supporting fifth graders in learning multiplication of fraction with whole number. Journal on Mathematics Education, 3(1), 71-86. https://doi.org/10.22342/jme.3.1.615.71-86

Khikmiyah, F., Lukito, A., \& Patahudin, S. M. (2012). Students' modelling in learning the concept of speed. Journal on Mathematics Education, 3(1), 87-98. https://doi.org/10.22342/jme.3.1.618.87-98

Komsiatun, E. (2018). Pengembangan LKS berbasis pendekatan realistic mathematics 
education untuk meningkatkan kemampuan matematis siswa. AKSIOMA: Jurnal Program Studi Pendidikan Matematika, 7(1), $155-160$. http://dx.doi.org/10.24127/ajpm.v7i1.1362

Kowiyah, K., Mulyawati, I., \& Umam, K. (2019). Conceptual understanding and mathematical representation analysis of realistic mathematics education based on personality types. Al-Jabar: Jurnal Pendidikan Matematika, 10(2), 201-210. https://doi.org/10.24042/ajpm.v10i2.4605

Krismiati, A. (2013). Penerapan pembelajaran dengan Pendidikan Matematika Realistik (PMR) secara berkelompok untuk meningkatkan kemampuan pemecahan masalah matematis siswa di kelas X SMA. Infinity Journal,2(2), 123-135. https://doi.org/10.22460/infinity.v2i2.p123-135

Kusumaningsih, W., Darhim, Herman, T., \& Turmudi. (2018). Improvement algebraic thinking ability using multiple representation strategy on realistic mathematics education. Journal on Mathematics Education, 9(2), 281-290. https://doi.org/10.22342/jme.9.2.5404.281-290

Kwon, O. N. (2002). Conceptualizing the Realistic Mathematics Education Approach in the Teaching and Learning of Ordinary Differential Equations.

Larsen, S. P. (2013). A local instructional theory for the guided reinvention of the group and isomorphism concepts. The Journal of Mathematical Behavior, 32(4), 712-725. https://doi.org/10.1016/j.jmathb.2013.04.006

Larsen, S., \& Zandieh, M. (2008). Proofs and refutations in the undergraduate mathematics classroom. Educational Studies in Mathematics, 67(3), 205-216. https://doi.org/10.1007/s10649-007-9106-0

Lestariningsih, Anwar, M., \& Setiawan, A. M. (2015). Investigating the act of design in discharge concept using pmri. Journal on Mathematics Education, 6(2), 50-59. https://doi.org/10.22342/jme.6.2.2164.129

Lismareni, N., Somakim, S., \& Kesumawati, N. (2015). Pengembangan bahan ajar materi aritmetika sosial menggunakan konteks bahan bakar minyak dengan pendekatan pendidikan matematika realistik indonesia di SMP. Jurnal Pendidikan Matematika, 9(1), 48-58. https://doi.org/10.22342/jpm.9.1.2186.48\%20-\%2058

Maisyarah, S., \& Prahmana, R. C. I. (2020). Pembelajaran luas permukaan bangun ruang sisi datar menggunakan pendekatan pendidikan matematika realistik Indonesia. Jurnal Elemen, 6(1), 68-88. https://doi.org/10.29408/jel.v6i1.1713

Meika, I., Suryadi, D., \& Darhim. (2019). Developing a local instruction theory for learning combinations. Infinity Journal, 8(2), https://doi.org/10.22460/infinity.v8i2.p157-166

Meryansumayeka, Darmawijoyo, Putri, R. I. I., \& Den Hertog, J. (2011). Structured arrangement supporting the development of splitting level in doing multiplication by number up to 20. Journal on Mathematics Education, 2(2), 199-214. https://doi.org/10.22342/jme.2.2.748.199

Misdalina, M., Zulkardi, \& Purwoko, P. (2009). Pengembangan materi integral untuk sekolah menengah atas (sma) menggunakan Pendekatan Pendidikan Matematika Realistik Indonesia (PMRI) di Palembang. Jurnal Pendidikan Matematika, 3(1), 6174. https://doi.org/10.22342/jpm.3.1.321. 
Muhtarom, M., Nizaruddin, N., Nursyahidah, F., \& Happy, N. (2019). The effectiveness of realistic mathematics education to improve students' multi-representation ability. Infinity Journal, 8(1), 21-30. https://doi.org/10.22460/infinity.v8i1.p21-30

Muncarno, M., \& Astuti, N. (2018). Pengaruh pendekatan RME terhadap hasil belajar matematika. AKSIOMA: Jurnal Program Studi Pendidikan Matematika, 7(1), 103113. http://dx.doi.org/10.24127/ajpm.v7i1.1356

Murdiyani, N. M., Zulkardi, Putri, R. I. I., Van Eerde, D., \& Van Galen, F. (2013). Developing a model to support students in solving subtraction. Journal on Mathematics Education, 4(1), 95-112. https://doi.org/10.22342/jme.4.1.567.95-112

Muttaqin, H., Putri, R. I. I., \& Somakim. (2017). Design research on ratio and proportion learning by using ratio table and graph with OKU Timur context at the 7 th grade. Journal on Mathematics Education, 8(2), 211-222. https://doi.org/10.22342/jme.8.2.3969.211-222

Nasution, M. F., Putri, R. I. I., \& Zulkardi. (2018). Rowing sport in learning fractions of the fourth grade students. Journal on Mathematics Education, 9(1), 69-79. https://doi.org/10.22342/jme.9.1.4270.69-80

NCTM. (2000). Principles Standards and for School Mathematics. United States of America

Niswarni, N. (2012). Peningkatan hasil belajar program linier melalui pendekatan matematika realistik di kelas X Jasa Boga 1 Sekolah Menengah Kejuruan Negeri 6 Palembang. Jurnal Pendidikan Matematika, 6(2), 19-29. https://doi.org/10.22342/jpm.6.2.4088.19-29

Nuraida, I., \& Amam, A. (2019). Hypothetical learning trajectory in realistic mathematics education to improve the mathematical communication of junior high school students. Infinity Journal, 8(2), https://doi.org/10.22460/infinity.v8i2.p247-258

247-258.

Nurdiansyah, \& Prahmana, R. C. I. (2017). Pembelajaran keliling lingkaran menggunakan konteks gelas. Jurnal Riset Pendidikan Matematika, 4(2), 128-140. https://doi.org/10.21831/jrpm.v4i2.14829

Nursyahidah, F., Putri, R. I. I., \& Somakim. (2013). Supporting first grade students' understanding of addition up to 20 using traditional game. Journal on Mathematics Education, 4(2), 212-223. https://doi.org/10.22342/jme.4.2.557.212-223

Nursyahidah, F., Saputro, B. A., \& Rubowo, M. R. (2018). A Secondary student's problem solving ability in learning based on realistic mathematics with ethnomathematics. JRAMathEdu (Journal of Research and Advances in Mathematics Education), 3(1), 13-24. https://doi.org/10.23917/jramathedu.v3i1.5607

Palinussa, A. L. (2013). Students' critical mathematical thinking skills and character: Experiments for junior high school students through realistic mathematics education culture-based. Journal on Mathematics Education, 4(1), 75-94. https://doi.org/10.22342/jme.4.1.566.75-94

Palupi, E. L. W. (2017). Pendekatan pendidikan matematika realistik indonesia berbantuan puzzle tangram untuk mengajarakan luas bangun datar gabungan. Jurnal Elemen, 3(2), 138. https://doi.org/10.29408/jel.v3i2.401

Paradita, L., Vahlia, I., \& ES, Y. R. (2019). Peningkatan kecerdasan intrapersonal dan hasil 
belajar melalui model pembelajaran take and give berbasis matematika realistik. AKSIOMA: Jurnal Program Studi Pendidikan Matematika, 8(3). http://dx.doi.org/10.24127/ajpm.v8i3.2473

Pramudiani, P., Zulkardi, Hartono, Y., \& Van Amerom, B. (2011). A concrete situation for learning decimals. Journal on Mathematics Education, 2(2), 215-230. https://doi.org/10.22342/jme.2.2.750.213

Pratama, S. E., Yahya, A. D., \& Pratiwi, D. D. (2019). Pengembangan alat peraga logika matematika miniatur tandon air tingkat tiga melalui Realistic Mathematics Education (RME). AKSIOMA: Jurnal Program Studi Pendidikan Matematika, 8(1), 121-132. http://dx.doi.org/10.24127/ajpm.v8i1.1749

Putra, F. G. (2016). Pengaruh model pembelajaran reflektif dengan pendekatan matematika realistik bernuansa keislaman terhadap kemampuan komunikasi matematis. $\mathrm{Al}$ Jabar: Jurnal Pendidikan Matematika, 7(2), 203-210. https://doi.org/10.24042/ajpm.v7i2.35

Putra, Z. H., Darmawijoyo, Putri, R. I. I., \& Den Hertog, J. (2011). Supporting first grade students learning number facts up to 10 using a parrot game. Journal on Mathematics Education, 2(2), 163-172. https://doi.org/10.22342/jme.2.2.776.163-172

Putri, R. I. I., \& Zulkardi. (2019). Designing jumping task on percent using PMRI and collaborative learning. International Journal on Emerging Mathematics Education, 3(1), 105. https://doi.org/10.12928/ijeme.v3i1.12208

Putria, A., Putri, R. I. I., \& Mulyono, B. (2015). Pembelajaran matematika pokok bahasan rata-rata hitung menggunakan pendekatan PMRI di kelas VII. Jurnal Pendidikan Matematika, 9(2), 148-161. http://dx.doi.org/10.22342/jpm.9.2.2430.148-161

Rahayu, T., Purwoko, P., \& Zulkardi. (2008). Pengembangan Instrumen Penilaian dalam Pendidikan Matematika Realistik Indonesia (PMRI) di SMPN 17 Palembang. Jurnal Pendidikan Matematika, 2(2). https://doi.org/10.22342/jpm.2.2.301.

Rahmawati, N. K., \& Amah, A. (2018). The differences of the student learning outcome using realistic mathematics learning approaches (PMR) and contextual learning approaches (CTL) on the Sets Material. Al-Jabar: Jurnal Pendidikan Matematika, 9(1), 63-71. https://doi.org/10.24042/ajpm.v9i1.2243

Rasmussen, C. L., \& King, K. D. (2000). Locating starting points in differential equations: A realistic mathematics education approach. International Journal of Mathematical Education in Science and Technology, 31(2), 161-172. https://doi.org/10.1080/002073900287219

Rasmussen, C., Kwon, O. N., Allen, K., Marrongelle, K., \& Burtch, M. (2006). Capitalizing on advances in mathematics and K-12 mathematics education in undergraduate mathematics: An inquiry-oriented approach to differential equations. Asia Pacific Education Review, 7(1), 85-93. https://doi.org/10.1007/BF03036787

Revina, S., \& Leung, F. K. S. (2018). Educational borrowing and mathematics curriculum: Realistic Mathematics Education in the Dutch and Indonesian primary curriculum. International Journal on Emerging Mathematics Education. http://dx.doi.org/10.12928/ijeme.v2i1.8025

Rianasari, V. F., Budayasa, I. K., \& Patahuddin, S. M. (2012). Supporting students' understanding of percentage. Journal on Mathematics Education, 3(1), 29-40. 
https://doi.org/10.22342/jme.3.1.621.29-40

Rifandi, R. (2016). Supporting students' reasoning about multiplication of fractions by constructing an array model. JRAMathEdu (Journal of Research and Advances in Mathematics Education), 1(2),

99-110. https://doi.org/10.23917/jramathedu.v1i2.3385

Risdiyanti, I., \& Prahmana, R. C. I. (2020). The learning trajectory of number pattern learning using barathayudha war stories and uno stacko. Journal on Mathematics Education, 11(1), 157-166. https://doi.org/10.22342/jme.11.1.10225.157-166

Rizkianto, I., Zulkardi, \& Darmawijaya. (2013). Constructing geometric properties of rectangle, square, and triangle in the third grade of Indonesian primary schools. Journal on Mathematics Education, 4(2), 160-171. https://doi.org/10.22342/jme.4.2.414.160-171

Saleh, M., \& Isa, M. (2015). Pembagian pecahan terintegrasi dengan konsep lain melalui pendidikan matematika realistik Indonesia. Infinity Journal, 4(1), 55-64. https://doi.org/10.22460/infinity.v4i1.p55-64

Saleh, M., Prahmana, R. C. I., Isa, M., \& Murni. (2018). Improving the reasoning ability of elementary school student through the Indonesian realistic mathematics education. Journal on Mathematics Education, 9(1), 41-53. https://doi.org/10.22342/jme.9.1.5049.41-54

Sari, A. P. (2014). Pengaruh Pendidikan Matematika Realistik Indonesia terhadap pemahaman konsep siswa pada materi untung dan persentase untung. Jurnal Pendidikan Matematika, 8(2), 1-19. http://dx.doi.org/10.22342/jpm.8.2.1862.1-19

Sari, D. I., \& Sari, N. (2019). Pengembangan perangkat pembelajaran berbasis realistic mathematics education pada materi aritmatika sosial. AKSIOMA: Jurnal Program Studi Pendidikan Matematika, 8(2), 310-322. http://dx.doi.org/10.24127/ajpm.v8i2.1954

Sari, E. A. P., Juniati, D., \& Patahudin, S. M. (2012). Early fractions learning of 3rd grade students in SD Laboratorium Unesa. Journal on Mathematics Education, 3(1), 1728. https://doi.org/10.22342/jme.3.1.617.17-28

Sari, W. R. (2016). Pengembangan Perangkat pembelajaran bangun ruang di SMP dengan pendekatan pendidikan matematika realistik. Jurnal Riset Pendidikan Matematika, 3(1), 109-121. https://doi.org/10.21831/jrpm.v3i1.10407

Sembiring, R. K. (2010). Pendidikan Matematika Realistik Indonesia (PMRI): Perkembangan dan tantangannya. Journal on Mathematics Education, 1(1), 11-16. https://doi.org/10.22342/jme.1.1.791.11-16

Septianawati, D. (2014). Efektivitas penerapan metode diskusi dengan Pendekatan Matematika Realistik (PMR) ditinjau dari tipe kepribadian siswa kelas VIII SMP Negeri di Kabupaten Lampung Timur. AKSIOMA: Jurnal Program Studi Pendidikan Matematika, 3(2). 55-64. http://dx.doi.org/10.24127/ajpm.v3i2.31

Setyaningsih, N., Rejeki, S., \& Ishartono, N. (2019). Developing realistic and child-friendly learning model for teaching mathematics. JRAMathEdu (Journal of Research and Advances in Mathematics $\quad$ Education), 4(2), https://doi.org/10.23917/jramathedu.v4i2.8112

Shanty, N. O. (2016). Investigating students' development of learning integer concept and 
integer addition. Journal on Mathematics Education, 7(2), 57-72. https://doi.org/10.22342/jme.7.2.3538.57-72

Shanty, N. O., Hartono, Y., Putri, R. I. I., \& De Haan, D. (2011). Design research on mathematics education: Investigating the progress of Indonesian fifth grade students' learning on multiplication of fractions with natural numbers. Journal on Mathematics Education, 2(2), 147-162. https://doi.org/10.22342/jme.2.2.749.147-162

Simanulang, J. (2014). Pengembangan bahan ajar materi himpunan konteks laskar pelangi dengan pendekatan Pendidikan Matematika Realistik Indonesia (PMRI) Kelas VII Sekolah Menengah Pertama. Jurnal pendidikan matematika,8(1), 43-54. http://dx.doi.org/10.22342/jpm.8.1.1859.43-54

Simanullang, J., Darmawijoyo, \& Somakim, S. (2013). Pengembangan bahan ajar himpunan dengan pendekatan pendidikan Matematika Realistik Indonesia kelas VII sekolah Menengah Pertama. Jurnal Pendidikan Matematika, 7(1), 11-18. https://doi.org/10.22342/jpm.7.1.4644.

Soedjadi, R. (2007). Inti dasar-dasar Pendidikan Matematika Realistik Indonesia. Jurnal Pendidikan Matematika, 1(2). https://doi.org/10.22342/jpm.1.2.807.

Sugiman, \& Kusumah, Y. S. (2010). Dampak pendidikan matematika realistik terhadap peningkatan kemampuan pemecahan masalah siswa SMP. Indonesian Mathematical Society Journal on Mathematics Education, 1(1), 41-52. https://doi.org/10.22342/jme.1.1.793.41-52

Suherman, S. (2015). Kreativitas siswa dalam memecahkan masalah matematika materi pola bilangan dengan Pendekatan Matematika Realistik (PMR). Al-Jabar: Jurnal Pendidikan Matematika, 6(1), 81-90. https://doi.org/10.24042/ajpm.v6i1.57

Sulastri, S., Marwan, M., \& Duskri, M. (2017). Kemampuan representasi matematis siswa SMP melalui pendekatan pendidikan matematika realistik. Beta: Jurnal Tadris Matematika, 10(1), 51-69. https://doi.org/10.20414/BETAJTM.V10I1.101

Syutaridho, S., Zulkardi, \& Hartono, Y. (2012). Pengembangan bahan ajar keliling, luas persegi dan persegi panjang dengan Pendekatan Pendidikan Matematika Realistik Indonesia. Jurnal Pendidikan Matematika, 6(1), 6380. https://doi.org/10.22342/jpm.6.1.4075.63-80

Taufik, N. I., Zulkardi, \& Somakim, S. (2012). Pengembangan materi ajar penghitungan volume menggunakan Pendekatan Pendidikan Matematika Realistik Indonesia di Sekolah Dasar. Jurnal Pendidikan Matematika, 6(1), 35-62. https://doi.org/10.22342/jpm.6.1.4074.35-62

Triyani, S., Putri, R. I. I., \& Darmawijoyo. (2012). Supporting student's ability in understanding Least Common Multiple (LCM) concept using storytelling. Journal on Mathematics Education, 3(2), 151-164. https://doi.org/10.22342/jme.3.2.572.151-164

Umbara, U., \& Nuraeni, Z. (2019). Implementation of realistic mathematics education based on adobe flash professional CS6 to improve mathematical literacy. Infinity Journal, 8(2), 167-178. https://doi.org/10.22460/infinity.v8i2.p167-178

Utami, C., \& Nirawati, R. (2018). Pengembangan kemampuan literasi matematis melalui model PJBL dengan pendekatan realistic saintific dan pengukuran berbasis PISA. AKSIOMA: Jurnal Program Studi Pendidikan Matematika,7(3), 345- 
355. http://dx.doi.org/10.24127/ajpm.v7i3.1543

Van den Heuvel-Panhuizen, M., \& Drijvers P. (2020a) Realistic Mathematics Education. In: Lerman S. (eds) Encyclopedia of Mathematics Education. Springer, Cham.

Van den Heuvel-Panhuizen, M., \& Drijvers, P. (2020b). Realistic mathematics education. Encyclopedia of mathematics education, 713-717. https://doi.org/10.1007/978-3030-15789-0_170

Van den Heuvel-Panhuizen, M., \& Wijers, M. (2005). Mathematics standards and curricula in the Netherlands. Zentralblatt für Didaktik der Mathematik, 37(4), 287-307. https://doi.org/10.1007/BF02655816

Wahyuni, D., Masykur, R., \& Pratiwi, D. D. (2019). Pengembangan multimedia pembelajaran matematika dengan pendekatan matematika realistik. AKSIOMA: Jurnal Program Studi Pendidikan Matematika, 8(1), 32-40. http://dx.doi.org/10.24127/ajpm.v8i1.1711

Walle, J. A. Van De, Karp, K. S., \& Bay-Williams, J. M. (2013). Elementary and Middle School Mathematics Teaching Developmentally (8 edition). USA: Pearson Education, Inc.

Wewe, M., \& Juliawan, I. W. (2019). Developing mathematical devices with characteristics realistic mathematics education. Al-Jabar: Jurnal Pendidikan Matematika, 10(1), 110. https://doi.org/10.24042/ajpm.v10i1.3884

Wibowo, A. (2017). Pengaruh pendekatan pembelajaran matematika realistik dan saintifik terhadap prestasi belajar, kemampuan penalaran matematis dan minat belajar. Jurnal Riset Pendidikan Matematika, 4(1), 1-10. https://doi.org/10.21831/jrpm.v4i1.10066

Winarti, D. W., Amin, S. M., Lukito, A., \& Van Gallen, F. (2012). Learning the concept of area and perimeter by exploring their relation. Journal on Mathematics Education, 3(1), 41-54. https://doi.org/10.22342/jme.3.1.616.41-54

Yilmaz, R. (2020). Prospective Mathematics Teachers' Cognitive Competencies on Realistic Mathematics Education. Journal on Mathematics Education, 11(1), 17-44. https://doi.org/10.22342/jme.11.1.8690.17-44

Yuberta, K. R., Zulkardi, Hartono, Y., \& Van Galen, F. (2011). Developing Student' s notion of measurement unit for area. Journal on Mathematics Education, 2(2), 173-184. https://doi.org/10.22342/jme.2.2.775.173-184

Yunisha, R., Prahmana, R. C. I., \& Sukmawati, K. I. (2016). Pengaruh pendekatan pendidikan matematika realistik terhadap kemampuan komunikasi matematis siswa kelas VII SMP. Jurnal Elemen, 2(2), 136-145. https://doi.org/10.29408/jel.v2i2.284

Yusmanita, S., Ikhsan, M., \& Zubainur, C. M. (2018). Penerapan Pendekatan matematika realistik untuk meningkatkan kemampuan operasi hitung perkalian. Jurnal Elemen, 4(1), 93. https://doi.org/10.29408/jel.v4i1.469

Zabeta, M., Hartono, Y., \& Putri, R. I. I. (2015). Desain pembelajaran materi pecahan menggunakan Pendekatan Pendidikan Matematika Realistik Indonesia (PMRI). Beta: Jurnal Tadris Matematika, 8(1), 86-99.

Zulkardi, \& Putri, R. I. I. (2010). Desain bahan ajar penjumlahan pecahan berbasis Pendidikan Matematika Realistik Indonesia (PMRI) untuk siswa kelas IV Sekolah Dasar Negeri 23 Indralaya. Jurnal Pendidikan Matematika, 4(2), 86-96. https://doi.org/10.22342/jpm.4.2.818. 
Zulkardi, Putri R. I. I., \& Wijaya A. (2020) Two decades of realistic mathematics education in Indonesia. In van den Heuvel-Panhuizen M. (eds), International Reflections on the Netherlands Didactics of Mathematics. ICME-13 Monographs. Cham: Springer. https://doi.org/10.1007/978-3-030-20223-1_18

Zulkardi. (2019). Celebration of a decade of JME. Journal on Mathematics Education, 10(1), V-VI. https://doi.org/10.22342/jme.10.1.6916.v-vi 